\title{
PENGEMBANGAN BAHAN AJAR FISIKA BERBASIS SAINS TEKNOLOGI MASYARAKAT (STM) BERBANTUAN MULTIMEDIA DI SMK NEGERI 3 PALU
}

\author{
Hajira, Unggul Wahyono dan Darsikin \\ e-mail: hajira_pidu@yahoo.com \\ Program Studi Pendidikan Fisika FKIP Universitas Tadulako \\ Jl. Soekarno Hatta Km. 9 Kampus Bumi Tadulako Tondo Palu - Sulawesi Tengah
}

\begin{abstract}
Abstrak - Tujuan penelitian adalah untuk mengembangkan dan mengetahui kelayakan bahan ajar fisika berbasis Sains Teknologi Masyarakat (STM) berbantuan Multimedia di SMK Negeri 3 Palu. Permasalahan dari penelitian adalah bagaimanakah pengembangan bahan ajar fisika berbasis Sains Teknologi Masyarakat (STM) berbantuan multimedia di SMK Negeri 3 Palu. Manfaat dalam penelitian adalah memudahkan siswa dalam memahami konsep-konsep fisika, dapat menjadi acuan guru-guru dalam usaha memperbaiki kualitas pembelajaran fisika dalam mengembangkan bahan ajarnya. Untuk mengetahui layak atau tidaknya bahan ajar tersebut maka dilakukan uji kelayakan terhadap produk. Bahan ajar ini di uji oleh satu orang ahli materi, satu guru fisika SMK Negeri 3 Palu, dan 10 siswa kelas XI SMK Negeri 3 Palu. Berdasarkan hasil analisis penilaian ahli media diperoleh skor rata-rata sebesar 3,00 dan dikategorikan "Baik ", analisis penilaian ahli materi diperoleh skor rata-rata sebesar 2,91 dan dikategorikan "Baik ", sedangkan hasil analisis penilaian respon siswa diperoleh skor rata-rata sebesar 3,35 dan dikategorikan "Sangat Setuju". Hasil penelitian menunjukkan bahwa bahan ajar yang dikembangkan dapat dijadikan sebagai salah satu media pembelajaran bagi siswa.
\end{abstract}

Kata Kunci : Bahan ajar, Sains Teknologi Masyarakat (STM), Multimedia.

\section{PENDAHULUAN}

IImu Pengetahuan dan Teknologi (IPTEK) di Era globalisasi ini sangat berkembang pesat. Perkembangan iptek mendorong terjadinya perubahan pola pikir manusia. Dalam hal ini ada beberapa manusia yang mengambil nilai positif dan negative akan kemajuan iptek. Kemajuan teknologi itu sendiri tak lepas dari perkembangan akan pengetahuan manusia mengenai apa yang mereka alami dalam kehidupan sehari-hari. Perkembangan iptek dalam kehidupan seharihari terutama dunia pendidikan khususnya pembelajaran Fisika sangat berkaitan sekali. Sebagai contoh, banyak sekali alat-alat yang diciptakan karena kemajuan IPTEK (televisi, Radio, Handphone, dan lain-lain).

Pada umumnya dalam kegiatan pembelajaran tenaga pendidik hanya menggunakan bahan ajar cetak, salah satunya buku pelajaran atau buku teks. Buku pelajaran dalam dunia pendidikan merupakan suatu kebutuhan pokok bagi guru maupun siswa sebagai pedoman dalam kegiatan pembelajaran sehingga dapat mencapai kompetensi yang diharapkan. Namun, kegiatan pembelajaran yang menggunakan bahan ajar cetak memiliki kelemahan yaitu pemaparan materi bersifat linear, kegiatan pembelajaran terpusat pada guru, materi ajar disajikan dalam bahasa yang sulit dimengerti oleh siswa dan bentuk informasi disajikan secara terbatas yaitu dalam bentuk teks dan gambar. Setiap materi pembelajaran mempunyai tingkat kesukaran yang bervariasi.

Perkembangan sains dan teknologi serta perubahan kondisi masyarakat yang sangat pesat ini mengharuskan para guru meningkatkan kemampuan dan mengembangkan keahliannya. Kini tugas guru semakin kompleks dan menantang, sehingga selalu ditunutut untuk mengembangkan kemampuannya, baik secara individu maupun kelompok. Tugas utama seorang guru adalah membantu siswa dalam belajar, yakni berupaya menciptakan situasi dan kondisi yang memungkinkan terjadinya proses pembelajaran.

Pemanfaatan teknologi komputer juga sudah pernah diteliti oleh beberapa peneliti, diantaranya Hermawan, dkk [1] menyatakan bahwa "pembelajaran dengan menggunakan aplikasi komputer memberikan kesempatan kepada peserta didik untuk belajar secara dinamis dan interaktif". Selain itu, ia juga menyatakan bahwa "Penggunaan aplikasi komputer sebagai media interaktif dapat menciptakan iklim belajar yang efektif bagi siswa yang lambat (slow learner), dan dapat 
memacu efektifitas belajar bagi siswa yang lebih cepat (fast learner)". Mushon [2] menyimpulkan bahwa "penggunaan media pembelajaran berbasis teknologi informasi dapat memperlancar proses pembelajaran dan mengoptimalkan hasil belajar".

\section{METODOLOGI PENELITIAN}

Penelitian ini menggunakan metode pengembangan yaitu metode penelitian yang digunakan untuk menghasilkan produk tertentu, dan menguji keefektifan produk tersebut. Sugiyono [3]

Teknis analisis yang digunakan untuk menganalisis data hasil validasi adalah perhitungan nilai rata-rata. Penentuan teknik analisis nilai rata-rata ini berdasarkan pendapat dari Arikunto [4] yang menyatakan bahwa :

$$
\bar{X}=\frac{\sum x}{n}
$$

Keterangan :

$$
\begin{array}{ll}
\overline{\boldsymbol{X}} & \text { : nilai rata-rata dalam tiap butir } \\
& \text { pertanyaan } \\
\sum \boldsymbol{x} & \text { : jumlah nilai dari seluruh penilaian } \\
& \text { dalam tiap butir pertanyaan. } \\
\boldsymbol{n} & \text { : jumlah butir pernyataan. }
\end{array}
$$

Mengubah skor rata-rata yang diperoleh ke dalam bentuk kualitatif berdasarkan tabel berikut Widoyoko [5]

Tabel 1 Kriteria Penilaian Produk
\begin{tabular}{|c|c|}
\hline Skor Rata-Rata & Kriteria \\
\hline $3,25<\bar{X} \leqslant 4,00$ & Sangat baik (SB) \\
\hline $2,50<\bar{X} \leqslant 3,25$ & Baik (B) \\
\hline $1,75<\bar{X} \leqslant 2,50$ & Kurang (K) \\
\hline $1,00 \leqslant \bar{X} \leqslant 1,75$ & Sangat Kurang (SK) \\
\hline
\end{tabular}

Analisis data respon siswa serupa dengan analisis kualitas penilaian produk. Rata-rata skor dari angket respon selanjutnya diubah ke dalam bentuk kualitatif berdasarkan tabel berikut:
Tabel 2 Kriteria Kategori Respon Siswa

\begin{tabular}{|c|c|}
\hline Skor Rata-Rata & Kategori \\
\hline $3,25<\bar{X} \leqslant 4,00$ & Sangat Setuju (SS) \\
\hline $2,50<\bar{X} \leqslant 3,25$ & Setuju (S) \\
\hline $1,75<\bar{X} \leqslant 2,50$ & Tidak Setuju (TS) \\
\hline $1,00 \leqslant \bar{X} \leqslant 1,75$ & Sangat Tidak Setuju \\
& (STS) \\
\hline
\end{tabular}

\section{HASIL DAN PEMBAHASAN}

A. Hasil Penelitian

1. Penilaian Ahli Media

\begin{tabular}{|c|c|c|}
\hline $\begin{array}{l}\text { INDIKATOR } \\
\text { PENILAIAN }\end{array}$ & BUTIR PENILAIAN & KET. \\
\hline \multirow[t]{2}{*}{$\begin{array}{l}\text { A. Ukuran } \\
\text { BahaAjar }\end{array}$} & $\begin{array}{l}\text { 1. Kesesuaian ukuran } \\
\text { bahan ajar dengan } \\
\text { standar ISO. }\end{array}$ & Baik \\
\hline & $\begin{array}{l}\text { 2. Kesesuaian ukuran } \\
\text { dengan materi isi } \\
\text { bahan ajar. }\end{array}$ & Baik \\
\hline \multirow[t]{5}{*}{$\begin{array}{l}\text { B. Desain } \\
\text { Sampul bahan } \\
\text { Ajar (Cover) }\end{array}$} & $\begin{array}{l}\text { 3. Penampilan unsur } \\
\text { tata letak pada } \\
\text { sampul muka, } \\
\text { belakang dan } \\
\text { punggung secara } \\
\text { harmonis memiliki } \\
\text { irama dan kesatuan } \\
\text { serta konsisten. }\end{array}$ & Baik \\
\hline & $\begin{array}{l}\text { 4. Menampilkan pusat } \\
\text { pandang (center } \\
\text { point) yang baik. }\end{array}$ & Baik \\
\hline & $\begin{array}{l}\text { 5. Warna unsur tata } \\
\text { letak harmonis dan } \\
\text { memperjelas fungsi. }\end{array}$ & Baik \\
\hline & $\begin{array}{l}\text { 6. Ukuran huruf judul } \\
\text { bahan ajar lebih } \\
\text { dominan dan } \\
\text { proporsional } \\
\text { dibandingkan } \\
\text { ukuran modul, } \\
\text { nama pengarang. }\end{array}$ & Baik \\
\hline & $\begin{array}{l}\text { 7. Tidak menggunakan } \\
\text { terlalu banyak } \\
\text { kombinasi jenis } \\
\text { huruf. }\end{array}$ & Baik \\
\hline
\end{tabular}

Aspek yang dinilai oleh ahli media meliputi kelayakan grafik, dan kelayakan bahasa. Hasil analisis penilaian menurut ahli media disajikan pada tabel berikut ini.

Tabel 3 Hasil Analisis Penilaian Kelayakan Kegrafikan 


\begin{tabular}{|c|c|c|}
\hline & $\begin{array}{l}\text { 8. } \\
\text { Menggambarkan } \\
\text { isi/materi ajar dan } \\
\text { mengungkapkan } \\
\text { karakter obyek. }\end{array}$ & Baik \\
\hline \multirow[t]{7}{*}{$\begin{array}{l}\text { C. Desain Isi } \\
\text { Bahan Ajar }\end{array}$} & $\begin{array}{l}\text { 9. Pemisahan antar } \\
\text { paragraf jelas }\end{array}$ & Baik \\
\hline & $\begin{array}{l}\text { 10. Bidang cetak dan } \\
\text { marjin } \\
\text { proporsional }\end{array}$ & Baik \\
\hline & $\begin{array}{l}\text { 11. Ilustrasi dan } \\
\text { keterangan } \\
\text { gambar (caption) }\end{array}$ & Baik \\
\hline & $\begin{array}{l}\text { 12. Penempatan } \\
\text { judul, subjudul, } \\
\text { ilustrasi dan } \\
\text { keterangan } \\
\text { gambar tidak } \\
\text { menggangu } \\
\text { pemahaman. }\end{array}$ & Baik \\
\hline & $\begin{array}{l}\text { 13. Tidak } \\
\text { Menggunakan } \\
\text { terlalu banyak jenis } \\
\text { huruf. }\end{array}$ & Baik \\
\hline & $\begin{array}{l}\text { 14. Jenjang / hierarki } \\
\text { judul - judul jelas, } \\
\text { konsisten dan } \\
\text { proporsional. }\end{array}$ & Baik \\
\hline & $\begin{array}{l}\text { 15. Mampu } \\
\text { Mengungkap } \\
\text { makna/ arti dari } \\
\text { objek. }\end{array}$ & Baik \\
\hline
\end{tabular}

Tabel 4 Hasil Analisis Penilaian Kelayakan Bahasa

\begin{tabular}{|c|c|c|}
\hline $\begin{array}{l}\text { INDIKATOR } \\
\text { PENILAIAN }\end{array}$ & BUTIR PENILAIAN & KET. \\
\hline \multirow[t]{3}{*}{ A. Lugas } & $\begin{array}{l}\text { 1. Ketepatan struktur } \\
\text { kalimat. }\end{array}$ & Baik \\
\hline & 2. Keefektifan kalimat. & Baik \\
\hline & 3. Kebakuan istilah & Baik \\
\hline B. Komunikatif & $\begin{array}{l}\text { 4. Pemahaman } \\
\text { terhadap pesan } \\
\text { atau informasi. }\end{array}$ & Baik \\
\hline \multirow[t]{2}{*}{$\begin{array}{l}\text { C. Dialogis dan } \\
\text { Interaktif }\end{array}$} & $\begin{array}{l}\text { 5. Kemampuan } \\
\text { emotivasi } \\
\text { peserta didik. }\end{array}$ & Baik \\
\hline & $\begin{array}{l}\text { 6. Kemampuan } \\
\text { mendorong } \\
\text { berpikir kritis }\end{array}$ & Baik \\
\hline \multirow[t]{2}{*}{$\begin{array}{l}\text { D. Kesesuaian } \\
\text { dengan } \\
\text { Perkembangan } \\
\text { Peserta didik }\end{array}$} & $\begin{array}{l}\text { 7. Kesesuaian dengan } \\
\text { perkembangan } \\
\text { intelektual peserta } \\
\text { didik. } \\
\end{array}$ & Baik \\
\hline & $\begin{array}{l}\text { 8. Kesesuaian dengan } \\
\text { tingkat } \\
\text { perkembangan } \\
\text { emosional peserta } \\
\text { didik }\end{array}$ & Baik \\
\hline \multirow{2}{*}{$\begin{array}{l}\text { D. Kesesuaian } \\
\text { dengan Kaidah } \\
\text { Bahasa }\end{array}$} & $\begin{array}{l}\text { 9. Ketepatan tata } \\
\text { bahasa. }\end{array}$ & Baik \\
\hline & 10. Ketepatan ejaan. & Baik \\
\hline
\end{tabular}

\begin{tabular}{|l|l|c|}
\hline $\begin{array}{l}\text { F.Penggunaan } \\
\text { istilah, simbol, } \\
\text { atau ikon. }\end{array}$ & $\begin{array}{l}\text { 11. Konsistensi } \\
\text { Penggunaan } \\
\text { istilah. }\end{array}$ & Baik \\
\cline { 2 - 3 } & $\begin{array}{l}\text { 12. Konsistensi } \\
\text { penggunaan } \\
\text { simbol atau ikon. }\end{array}$ & Baik \\
\hline
\end{tabular}

2. Penilaian Ahli Materi

Aspek yang dinilai oleh ahli materi meliputi kelayakan isi, kelayakan penyajian, dan penilaian kontekstual. Hasil analisis penilaian menurut ahli materi disajikan pada tabel berikut ini.

Tabel 5 Hasil Analisis Penilaian Kelayakan Isi

\begin{tabular}{|c|c|c|}
\hline $\begin{array}{l}\text { INDIKATOR } \\
\text { PENILAIAN }\end{array}$ & BUTIR PENILAIAN & KET. \\
\hline \multirow{3}{*}{$\begin{array}{l}\text { A. Kesesuaian } \\
\text { Materi dengan } \\
\text { SK dan KD }\end{array}$} & 1. Kelengkapan materi & Baik \\
\hline & 2. Keluasan materi. & Baik \\
\hline & 3. Kedalaman materi. & Kurang \\
\hline \multirow{7}{*}{$\begin{array}{l}\text { B. Keakuratan } \\
\text { Materi }\end{array}$} & $\begin{array}{l}\text { 4. Keakuratan konsep } \\
\text { dan definisi. }\end{array}$ & Baik \\
\hline & $\begin{array}{l}\text { 5. Keakuratan data } \\
\text { dan fakta. }\end{array}$ & Baik \\
\hline & $\begin{array}{l}\text { 6. Keakuratan contoh } \\
\text { dan kasus }\end{array}$ & $\begin{array}{c}\text { Sangat } \\
\text { Baik }\end{array}$ \\
\hline & $\begin{array}{l}\text { 7. Keakuratan Gambar, } \\
\text { diagram dan ilustrasi }\end{array}$ & $\begin{array}{c}\text { Sangat } \\
\text { Baik }\end{array}$ \\
\hline & $\begin{array}{l}\text { 8. Keakuratan istilah- } \\
\text { istilah. }\end{array}$ & Baik \\
\hline & $\begin{array}{l}\text { 9. Keakuratan notasi, } \\
\text { simbol, dan ikon. }\end{array}$ & Kurang \\
\hline & $\begin{array}{l}\text { 10. Keakuratan acuan } \\
\text { pustaka. }\end{array}$ & Baik \\
\hline \multirow[t]{3}{*}{$\begin{array}{l}\text { C. Kemutakhiran } \\
\text { Materi }\end{array}$} & $\begin{array}{l}\text { 11. Kesesuaian materi } \\
\text { Dengan } \\
\text { perkembangan } \\
\text { ilmu Geometri. }\end{array}$ & Baik \\
\hline & $\begin{array}{l}\text { 12. Contoh dan kasus } \\
\text { dalam kehidupan } \\
\text { sehari-hari. }\end{array}$ & $\begin{array}{c}\text { Sangat } \\
\text { Baik }\end{array}$ \\
\hline & $\begin{array}{l}\text { 13. Gambar, diagram } \\
\text { dan ilustrasi } \\
\text { dalam kehidupan } \\
\text { sehari-hari }\end{array}$ & $\begin{array}{c}\text { Sangat } \\
\text { Baik }\end{array}$ \\
\hline
\end{tabular}




\begin{tabular}{|l|c|c|}
\hline & $\begin{array}{c}\text { 14. Menggunakan } \\
\text { contoh kasus } \\
\text { yang terdapat } \\
\text { dalam kehidupan } \\
\text { sehari-hari. }\end{array}$ & $\begin{array}{c}\text { Sangat } \\
\text { Baik }\end{array}$ \\
\cline { 2 - 3 } & $\begin{array}{l}\text { 15. Kemutakhiran } \\
\text { pustaka. }\end{array}$ & Baik \\
\hline $\begin{array}{l}\text { D. Mendorong } \\
\text { Keingintahuan }\end{array}$ & $\begin{array}{c}\text { 16. Mendorong rasa } \\
\text { ingin tahu. }\end{array}$ & Baik \\
\hline & $\begin{array}{c}\text { 17. Menciptakan } \\
\text { kemampuan } \\
\text { bertanya }\end{array}$ & Baik \\
\hline
\end{tabular}

Tabel 6 Hasil Analisis Penilaian Kelayakan Penyajian

\begin{tabular}{|c|c|c|}
\hline $\begin{array}{l}\text { INDIKATOR } \\
\text { PENILAIAN }\end{array}$ & BUTIR PENILAIAN & KET. \\
\hline \multirow[t]{2}{*}{$\begin{array}{l}\text { A. Teknik } \\
\text { Penyajian }\end{array}$} & $\begin{array}{l}\text { 1. Konsistensi } \\
\text { sistematika sajian } \\
\text { dalam kegiatan } \\
\text { belajar }\end{array}$ & Baik \\
\hline & 2. Keruntutan konsep. & Baik \\
\hline \multirow[t]{8}{*}{$\begin{array}{l}\text { B. Pendukung } \\
\text { Penyajian }\end{array}$} & $\begin{array}{l}\text { 3. Contoh-contoh soal } \\
\text { dalam setiap } \\
\text { kegiatan belajar. }\end{array}$ & Kurang \\
\hline & $\begin{array}{l}\text { 4. Soal latihan pada } \\
\text { setiap akhir } \\
\text { kegiatan belajar }\end{array}$ & Baik \\
\hline & $\begin{array}{l}\text { 5. Kunci jawaban soal } \\
\text { latihan. }\end{array}$ & Kurang \\
\hline & $\begin{array}{l}\text { 6. Umpan balik soal } \\
\text { latihan. }\end{array}$ & Kurang \\
\hline & 7. Pengantar. & Baik \\
\hline & 8. Glosarium. & Baik \\
\hline & 9. Daftar Pustaka. & Baik \\
\hline & 10. Rangkuman. & Baik \\
\hline $\begin{array}{l}\text { C. Penyajian } \\
\text { Pembelajaran }\end{array}$ & $\begin{array}{l}\text { 11. Keterlibatan } \\
\text { peserta didik. }\end{array}$ & $\begin{array}{c}\text { Sangat } \\
\text { Baik }\end{array}$ \\
\hline \multirow{2}{*}{$\begin{array}{l}\text { D. Koherensi } \\
\text { dan } \\
\text { Keruntutan } \\
\text { Alur Pikir }\end{array}$} & $\begin{array}{l}\text { 12. Ketertautan antar } \\
\text { kegiatan belajar / } \\
\text { sub kegiatan } \\
\text { belajar/ alinea. }\end{array}$ & $\begin{array}{l}\text { Sangat } \\
\text { Baik }\end{array}$ \\
\hline & $\begin{array}{l}\text { 13. Keutuhan makna } \\
\text { dalam kegiatan } \\
\text { belajar / sub } \\
\text { kegiatan belajar/ } \\
\text { alinea. }\end{array}$ & Baik \\
\hline
\end{tabular}

Tabel 7 Hasil Analisis Penilaian Kontekstual

\begin{tabular}{|c|c|c|}
\hline $\begin{array}{c}\text { INDIKATOR } \\
\text { PENILAIAN }\end{array}$ & BUTIR PENILAIAN & KET. \\
\hline $\begin{array}{l}\text { A. Hakikat } \\
\text { Kontekstual }\end{array}$ & $\begin{array}{l}\text { 1. Keterkaitan antara } \\
\text { Materi yang } \\
\text { diajarkan dengan } \\
\text { situasi dunia nyata } \\
\text { siswa. }\end{array}$ & $\begin{array}{c}\text { Sangat } \\
\text { Baik }\end{array}$ \\
\hline
\end{tabular}

\begin{tabular}{|c|c|c|}
\hline & $\begin{array}{l}\text { 2. Kemampuan } \\
\text { Mendorong siswa } \\
\text { membuat hubungan } \\
\text { antara pengetahuan } \\
\text { yang dimiliki siswa } \\
\text { dengan } \\
\text { penerapannya } \\
\text { dalam kehidupan } \\
\text { sehari-hari siswa. }\end{array}$ & Baik \\
\hline \multirow{7}{*}{$\begin{array}{l}\text { B. Komponen } \\
\text { Kontekstual }\end{array}$} & $\begin{array}{l}\text { 3. Konstruktivisme } \\
\text { (Constructivism). }\end{array}$ & Kurang \\
\hline & $\begin{array}{l}\text { 4. Menemukan } \\
\text { (Inkuiry). }\end{array}$ & Baik \\
\hline & $\begin{array}{l}\text { 5. Bertanya } \\
\text { (Questioning). }\end{array}$ & Baik \\
\hline & $\begin{array}{l}\text { 6. Masyarakat Belajar } \\
\text { (Learning Community) }\end{array}$ & Kurang \\
\hline & $\begin{array}{l}\text { 7. Pemodelan } \\
\text { (Modelling) }\end{array}$ & Baik \\
\hline & $\begin{array}{l}\text { 8. Refleksi } \\
\text { (Reflection). }\end{array}$ & Kurang \\
\hline & $\begin{array}{l}\text { 9. Penilaian yang } \\
\text { Sebenarnya } \\
\text { (Authentic } \\
\text { Assessment). }\end{array}$ & Kurang \\
\hline
\end{tabular}

\section{Respon Siswa}

Uji terbatas bertujuan untuk mengetahui respon siswa terhadap penggunaan bahan ajar ini. Bahan ajar hasil pengembangan diujikan dalam uji coba lapangan skala kecil kepada sepuluh siswa.

Tabel 8 Hasil Analisis Rata-Rata Penilaian Berdasarkan 10 Respon Siswa

\begin{tabular}{|c|c|c|}
\hline NO & PERNYATAAN & KET. \\
\hline 1 & $\begin{array}{l}\text { Bahan ajar ini menjelaskan suatu } \\
\text { konsep menggunakan ilustrasi masalah } \\
\text { yang berkaitan dengan kehidupan } \\
\text { sehari-hari. }\end{array}$ & Setuju \\
\hline 2 & $\begin{array}{l}\text { Bahan ajar ini menggunakan contoh- } \\
\text { contoh soal yang berkaitan dengan } \\
\text { masalah kehidupan sehari-hari. }\end{array}$ & $\begin{array}{l}\text { Sangat } \\
\text { Setuju }\end{array}$ \\
\hline 3 & $\begin{array}{l}\text { Penyajian materi dalam bahan ajar } \\
\text { dimulai dari yang mudah ke sukar dan } \\
\text { dari yang konkret ke abstrak }\end{array}$ & Setuju \\
\hline 4 & $\begin{array}{l}\text { Dalam bahan ajar ini terdapat beberapa } \\
\text { bagian untuk saya menemukan konsep } \\
\text { sendiri. }\end{array}$ & Setuju \\
\hline 5 & $\begin{array}{l}\text { Bahan ajar ini memuat pertanyaan- } \\
\text { pertanyaan yang mendorong saya untuk } \\
\text { belajar. }\end{array}$ & $\begin{array}{l}\text { Sangat } \\
\text { Setuju }\end{array}$ \\
\hline 6 & $\begin{array}{l}\text { Penyajian materi dalam bahan ajar ini } \\
\text { mendorong saya untuk berdiskusi } \\
\text { dengan teman-teman yang lain. }\end{array}$ & $\begin{array}{l}\text { Sangat } \\
\text { Setuju }\end{array}$ \\
\hline 7 & $\begin{array}{l}\text { Materi bahan ajar ini mendorong } \\
\text { keingintahuan saya. }\end{array}$ & $\begin{array}{l}\text { Sangat } \\
\text { Setuju }\end{array}$ \\
\hline 8 & $\begin{array}{l}\text { Bahan ajar ini mendorong saya untuk } \\
\text { merangkum materi sendiri pada kolom } \\
\text { "Refleksi". }\end{array}$ & Setuju \\
\hline
\end{tabular}




\begin{tabular}{|c|l|c|}
\hline 9 & $\begin{array}{l}\text { Bahan ajar ini memuat tes formatif yang } \\
\text { dapat menguji seberapa jauh } \\
\text { pemahaman saya tentang materi } \\
\text { Termodinamika. }\end{array}$ & $\begin{array}{c}\text { Sangat } \\
\text { Setuju }\end{array}$ \\
\hline 10 & $\begin{array}{l}\text { Kalimat dan paragraf yang digunakan } \\
\text { dalam bahan ajar ini jelas dan mudah } \\
\text { dipahami. }\end{array}$ & Setuju \\
\hline 11 & $\begin{array}{l}\text { Bahasa yang digunakan sederhana dan } \\
\text { mudah dimengerti. }\end{array}$ & $\begin{array}{c}\text { Sangat } \\
\text { Setuju }\end{array}$ \\
\hline 12 & $\begin{array}{l}\text { Huruf yang digunakan sederhana dan } \\
\text { mudah dibaca. }\end{array}$ & $\begin{array}{c}\text { Sangat } \\
\text { Setuju }\end{array}$ \\
\hline 13 & $\begin{array}{l}\text { Tampilan bahan ajar ini menarik. } \\
\text { Sangat } \\
\text { Setuju }\end{array}$ \\
\hline 14 & $\begin{array}{l}\text { Bahan ajar ini membuat saya senang } \\
\text { mempelajari Fisika. }\end{array}$ & $\begin{array}{c}\text { sangat } \\
\text { Setuju }\end{array}$ \\
\hline 15 & $\begin{array}{l}\text { Dengan menggunakan bahan ajar ini } \\
\text { dapat menambah keinginan untuk } \\
\text { belajar. }\end{array}$ & $\begin{array}{c}\text { Sangat } \\
\text { Setuju }\end{array}$ \\
\hline 16 & $\begin{array}{l}\text { Dengan menggunakan bahan ajar ini } \\
\text { membuat belajar saya lebih terarah dan } \\
\text { runtut. }\end{array}$ & Setuju \\
\hline 17 & $\begin{array}{l}\text { Dengan adanya ilustrasi di setiap awal } \\
\text { materi dapat memberikan motivasi } \\
\text { untuk mempelajari materi. }\end{array}$ & $\begin{array}{c}\text { Sangat } \\
\text { Setuju }\end{array}$ \\
\hline 18 & $\begin{array}{l}\text { Dengan menggunakan bahan ajar ini } \\
\text { dapat membuat belajar fisika tidak } \\
\text { membosankan. }\end{array}$ & $\begin{array}{l}\text { Sangat } \\
\text { Setuju }\end{array}$ \\
\hline
\end{tabular}

\section{B. Pembahasan}

Penelitian ini bertujuan untuk mengembangkan bahan ajar fisika berbasis Sains Teknologi Masyarakat (STM) berbantuan multimedia di Sekolah SMK Yaitu SMK Negeri 3 Palu. Dalam pengembangan bahan ajar ini diharapkan bermanfaat kepada siswa dalam memudahkan memahami konsep-konsep fisika, dapat menjadi acuan guru-guru dalam usaha memperbaiki kualitas pembelajaran fisika dalam mengembangkan bahan ajarnya, dan diharapkan dapat dijadikan tambahan referensi untuk penelitian selanjutnya tentang pengembangan bahan ajar fisika berbasis Sains Teknologi Masyarakat (STM). Fungsi dari penyusunan bahan ajar adalah sebagai pedoman bagi siswa yang mengarahkan semua aktivitasnya dalam proses pembelajaran, sekaligus merupakan subtansi kopetensi yang seharusnya dipelajari, pedoman bagi tenaga pendidik yang akan mengarahkan semua aktivitasnya dalam proses pembelajaran, sekaligus merupakan subtansi kopetensi yang seharusnya diajarkan kepada siswanya dan sebagai alat evaluasi pencapaian hasil pembelajaran siswa.

Pada penelitian ini pengembangan bahan ajar fisika berbasis Sains Teknologi Masyarakat (STM) berbantun multimedia yang dimaksud adalah peristiwa termodinamika yang terjadi disekitar masyarakat yang nantinya akan di simulasikan di multimedia khususnya media pembelajaran berbasis EXE. Dari beberapa contoh Sains Teknologi Masyarakat yang disimulasikan di $E X E$, salah satunya adalah motor 2 tack dimana motor 2 tack yang biasa kita jumpi di masyarakat merupakan aplikasi Hukum Kedua Termodinamika yang sangat erat kaitannya dengan target sasaran penelitian yaitu siswa SMK Negeri 3 Palu lebih khususnya Jurusan Teknik Mekanik Otomotif (TMO).

Berdasarkan penilaian ahli media yang dilakukan oleh dosen fisika universitas tadulako yaitu pada tanggal 20 Oktober 2014, aspek yang dinilai dari bahan ajar ini meliputi kelayakan kegrafikan dan kelayakan bahasa. Adapun indikator yang di nilai pada aspek kelayakan kegrafikan yaitu ukuran bahan ajar, desain sampul bahan ajar, dan desain isi bahan ajar.

Selanjutnya pada tampilan desain awal, dimana komponen yang di nilai oleh ahli media adalah penampilan unsur tata letak pada desain awal, tampilan bahan ajar dan simulasi secara harmonis memiliki irama dan kesatuan serta konsisten. Desain awal, tampian serta simulasi merupakan suatu kesatuan yang utuh. Elemen warna, ilustrasi, dan tipografi ditampilkan secara harmonis dan saling terkait satu dan lainnya. Dari hasil tersebut sudah sesuai dengan yang di harapkan sehingga menurut ahli media masing-masing komponen tersebut dalam kategori baik.

Selanjutnya desain isi bahan ajar, komponen yang di nilai adalah pemisahan antar paragraf jelas, bidang cetak dan marjin proporsional, ilustrasi dan keterangan gambar (caption), penempatan judul, subjudul, ilustrasi dan keterangan gambar tidak menggangu pemahaman, tidak menggunakan terlalu banyak jenis huruf, jenjang / hirarki judul-judul jelas, konsisten dan proporsional, mampu mengungkap makna/ arti dari objek. Dimana komponen tersebut sudah sesuai dengan deskripsi yang di harapkan bahwa Susunan teks pada akhir paragraf terpisah dengan jelas, dapat berupa jarak (pada susunan teks rata kiri-kanan/blok) ataupun dengan inden (pada susunan teks dengan alenia). Dari hasil yang diperoleh dari ahli media bahwa komponen tersebut sudah sesuai dengan yang diharapkan pada deskripsi dan di kategorikan baik.

Penilaian ahli media pada aspek kelayakan bahasa yang meliputi ketepatan struktur kalimat, diharapkan kalimat yang digunakan mewakili isi pesan atau informasi yang ingin disampaikan dengan tetap mengikuti tata kalimat Bahasa Indonesia. Keefektifan kalimat yang digunakan sederhana dan 
langsung kesasaran. Kebakuan istilah menurut ahli media adalah Istilah yang digunakan sesuai dengan kamus Besar Bahasa Indonesia dan / atau adalah istilah teknis yang telah baku digunakan dalam Fisika. Dari hasil penilaian aspek kelayakan bahasa tersebut masingmasing komponen dalam kategori baik.

Selanjutnya Berdasarkan penilaian ahli materi yang dilakukan oleh seorang guru fisika pada tanggal 01 Desember 2014, aspek yang dinilai dari bahan ajar ini meliputi kelayakan isi, kelayakan penyajian, dan penilaian kontekstual. Dari penilaian kelayakan isi terdapat beragam jawaban dari ahli materi. Menurut ahli materi pada butir penilaian kedalaman materi itu masih kurang karena Materi yang disajikan mulai dari pengenalan konsep, definisi, prosedur, tampilan output, contoh, kasus, latihan, sampai dengan interaksi antar-konsep belum sesuai dengan tingkat pendidikan di Sekolah Menengah atas dan sesuai dengan yang diamanatkan oleh Kompetensi Dasar (KD). Kemudian pada keakuratan, notasi, simbol, dan ikon juga masih kurang karena menurut ahli materi pada bahan ajar ini masih kurang terdapat simbol-simbol yang digunakan pada rumus yang harusnya notasi, simbol, dan ikon disajikan secara benar menurut kelaziman yang digunakan dalam bidang/ilmu fisika. Dan pada butir penilaian keakuratan contoh dan kasus yang disajikan sudah sesuai dengan kenyataan dan efisien untuk meningkatkan pemahaman peserta didik, keakuratan gambar, diagram, dan ilustrasi yang disajikan sudah sesuai dengan kenyataan, contoh dan kasus dalam kehidupan sehari-hari sudah sesuai dengan perkembangan ilmu fisika dan terdapat dalam kehidupan sehari-hari, gambar, diagram dan ilustrasi diutamakan yang terdapat dalam kehidupan sehari-hari dan juga dilengkapi penjelasan, dan penggunakan contoh kasus disajikan sesuai dengan situasi serta kondisi yang terjadi dalam kehidupan sehari-hari sehingga dalam penilaian kategori sangat baik. Dan untuk penilaian kelayakan isi lainnya sudah dalam kategori baik namun perlu direvisi lagi agar dapat mencapi kesempurnaan.

Selajutnya ahli materi menilai aspek kelayakan penyajian yang dinilai adalah sistematika penyajian dalam setiap kegiatan belajar taat asas (memiliki pendahuluan, isi dan penutup), penyajian konsep disajikan secara runtut mulai dari yang mudah ke sukar, dari yang konkret ke abstrak dan dari yang sederhana ke kompleks, dari yang dikenal sampai yang belum dikenal dan materi bagian sebelumnya bisa membantu pemahaman materi pada bagian selanjutnya. Soal-soal yang diberikan sudah dapat melatih kemampuan memahami dan menerapkan konsep yang berkaitan dengan materi dalam kegiatan belajar sehingga menurut ahli materi sudah dalam kategori baik dan perlu direvisi lagi agar lebih sempurna. Dari hasil tersebut diharapkan untuk merevisi kembali bagian-bagian yang di anggap masih kurang khususnya pada contoh-contoh soal dan penyelesaianya.

Setelah dilakukan validasi ahli media dan ahli materi langkah selanjutnya adalah uji skala kecil atau uji terbatas. Uji terbatas ini bertujuan untuk mengetahui respon siswa terhadap penggunaan bahan ajar ini. Hasil analisis respon siswa terhadap bahan ajar fisika materi Termodinamika berbasis Sains Teknologi Masyarakat (STM) berbantuan Multimedia yang dikembangkan karena tipe pernyataannya bersifat positif, maka nilai (score) untuk tiap pilihan jawabannya adalah sebagai berikut 4 (Sangat setuju), 3 (Setuju), 2 (Tidak setuju), dan 1 (Sangat tidak setuju). Adapun jumlah pernyataan yang diberikan berjumlah 18 item dengan indikator yang dinilai oleh siswa adalah materi, bahasa, dan ketertarikan pada bahan ajar.

Pada pernyataan 1 ada dua siswa yang menjawab sangat setuju karena bahan ajar ini sudah menjelaskan suatu konsep menggunakan ilustrasi masalah yang berkaitan dengan kehidupan sehari-hari, sedangkan siswa lainnya menjawab setuju. Pada pernyataan 2 ada tujuh siswa menjawab setuju sedangkan tiga siswa lainnya menjawab sangat setuju karena bahan ajar ini sudah menggunakan contoh-contoh soal yang berkaitan dengan masalah kehidupan sehari-hari. Pernyataan 3 yang menyatakan penyajian materi dalam bahan ajar dimulai dari yang mudah ke sukar dan dari yang konkret ke abstrak, dimana pada pernyataan ini ada 8 siswa menjawab setuju dan dua siswa lainnya menjawab sangat setuju. Pada pernyataan 4 yang isi pernyataannya tentang respon siswa mengenai apakah bahan ajar ini mendorong siswa untuk menemukan konsep sendiri, dari respon siswa didapatkan ada 1 siswa yang menjawab kurang seteju, hal itu di karenakan siswa tersebut kurang menyimak penjelasan materi termodinamika dan mungkin juga siswa kurang memahami isi pernyataan tersebut. Pada Pernyataan 5, 6, dan 7 rata-rata siswa menjawab sangat setuju karena menurut siswa dalam bahan ajar ini sudah terdapat beberapa bagian untuk siswa, memuat pertanyaan- 
pertanyaan yang mendorong siswa untuk belajar, dapat mendorong siswa untuk berdiskusi dengan teman-teman yang lain, dan materi bahan ajar ini mendorong keingintahuan siswa dalam belajar. Kemudian pada pernyataan 8 ada dua siswa menjawab kurang setuju dan dua siswa menjawab sangat setuju dan 6 siswa lainnya menjawab setuju, dua siswa menjawab kurang setuju di karenakan siswa tersebut kurang memahami kata 'Refleksi' sementara siswa lainnya menjawab setuju dan sangat setuju, karena diharapkan bahan ajar ini dapat mendorong siswa merangkum materi sendiri. Pada pernyataan 9, rata- rata siswa menjawab sangat setuju bahan ajar ini diharapkan dapat membantu siswa memahami materi termodinamika melalui tes formatif yang ada pada bahan ajar. Pada Pernyataan 10, terdapat delapan siswa menjawab setuju dan dua siswa lainnya menjawab sangat setuju, pada pernyataan 10 memuat mengenai kalimat dan paragraph yang digunakan dalam bahan ajar ini jelas dan mudah dipahami, dari respon siswa yang ratarata siswa menjawab setuju itu berarti kalimat dan paragraf pada bahan ajar ini mudah dipahami oleh siswa, dan peneliti juga berharap bahan ajar ini dapat membantu memahami materi-materi termodinamika melalui kalimat yang lebih sederhana yang terdapat pada bahan ajar ini. Pada Pernyataan 11, 12, 13, 14 dan 15 rata-rata siswa menjawab sangat setuju yang menyatakan bahasa yang digunakan sederhana dan mudah dimengerti, huruf yang digunakan sederhana dan mudah dibaca, dan tampilan bahan ajar ini sangat menarik, huruf yang digunakan sederhana dan mudah dibaca, bahan ajar ini membuat siswa senang mempelajari fisika, dan bahan ajar ini juga dapat membuat dan menambah keinginan siswa untuk belajar. Pada pernyataan 16 ada satu siswa menjawab kurang, 6 siswa menjawab setuju dan tiga siswa menjawab sangat setuju yang mennyatakan bahwa dengan adanya bahan ajar ini membuat siswa lebih terarah sementara satu siswa menjawab kurang setuju dikarenakan siswa tersebut belum merasa terarah dalam belajar fisika ketika membaca bahan ajar ini. Pada pernyataan 17, dan 18 siswa rata-rata menjawab sangat setuju dimana pada pernyataan 17 dan 18 lebih memotivasi siswa dalam belajar fisika dan membuat siswa tidak merasa bosan dalam belajar fisika.

Selanjutnya untuk mengetahui data kuantitatif maka akan dilakukan perhitungan menggunakan rumus yang sudah ada. Yang pertama adalah pada hasil perhitungan uji ahli media yang dilakukan oleh satu dosen fisika universitas tadulako. Dimana Rata-rata hasil penilaian dari uji kelayakan kegrafikan adalah 3,06 dan rata-rata hasil penilaian dari uji kelayakan bahasa adalah 3,00. Hasil rata-rata penilaian uji kelayakan kegrafikan dan uji kelayakan bahasa didapatkan jumlah rata-rata keseluruhan dari ahli media yaitu 3,03 dan di kateorikan "Baik ". Dari hasil tersebut ahli media menyatakan bahwa bahan ajar ini layak di uji cobakan di lapangan dengan revisi.

Selanjutnya pada hasil penilaian ahli materi yang dilakukan oleh guru fisika SMK Negeri 3 Palu yaitu Ibu Thithis Yuli. A, ST. aspek yang di nilai dari bahan ajar ini meliputi kelayakan isi, kelayakan penyajian, dan penilaian kontekstual. Rata-rata penilaian kelayakan isi adalah 3,17 , kelayakan penyajian 2,92 , dan penilaian kontekstual 2,66. Dari hasil rata-rata penilaian kelayakan isi, kelayakan penyajian, dan penilaian kontekstual didapatkan jumlah rata-rata keseluruhan dari ahli materi yaitu 2,91 dan di kategorikan " Baik".

Selanjutnya uji terbatas yang dilakukan terhadap sepuluh siswa kelas XI SMK Negeri 3 Palu, siswa diberi angket yang mempunyai 18 item pernyataan dan ada 4 opsi pilihan. Setelah melakukan analisis terhadap angket yang diberian kepada siswa, didapatkan skor ratarata sebesar 3,35. Berdasarkan Tabel 8 yaitu kriteria kategori respon siswa, skor tersebut termasuk ke dalam kategori "Sangat Setuju ". Karena hasil angket menunjukkan kategori Sangat setuju maka bisa dikatakan bahwa bahan ajar yang dibuat layak digunakan untuk media belajar mandiri siswa.

\section{KESIMPULAN}

Berdasarkan analisis dan pembahasan di atas, maka dapat disimpulkan bahwa bahan ajar yang dikembangkan ini dapat dijadikan sebagai salah satu media pembelajaran bagi siswa. Hal ini berdasarkan Pada hasil uji coba ahli media didapatkan skor penilain rata-rata sebesar 3,00 dan dikategorikan Baik, analisis penilaian ahli materi didapatkan skor rata-rata sebesar 2,91 dan dikategorikan "Baik", sedangkan hasil analisis penilaian respon siswa didapatkan skor rata-rata sebesar 3,35 dan dikategorikan "Sangat setuju". 


\section{DAFTAR PUSTAKA}

[1] Hermawan, dkk. 2008. Pengembangan bahan ajar. Jakarta: UPI (KTI)

[2] Mushon, Ali. 2010. Pengembangan Media Pembelajaran Berbasis Teknologi Informasi. (online), (http://alimushon.wordpress.com, diakses 10/01/2013).

[3] Arikunto, S. 2006. Prosedur Penelitian: Suatu Pendekatan Praktik. Jakarta: Bineka Cipta

[4] Sugiyono. 2010. Metode Penelitian Pendidikan Kuantitatif, kualitatif, dan $R$ \& $D$. Bandung : Alfabeta.

[5] Widoyoko. 2012. Teknik Penyusunan Instrumens Penelitian. Yogyakarta: Pustaka Pelajar. 